\title{
Influence of Feeding Peanut Skins on Performance of Gulf Coast Ewe Lambs
}

\author{
G. M. Abdelrahim ${ }^{*}$, J. Khatiwada ${ }^{2}$, D. Rankins ${ }^{3}$, N. Gurung ${ }^{4}$, A. Gueye ${ }^{5}$
}

${ }^{1}$ Department of Food and Animal Sciences, Alabama A \& M University, Normal, AL, 35762; ${ }^{2}$ Department of Family and Consumer Sciences, North Carolina A\&T State University, Greensboro, North Carolina, 2741 1; ${ }^{3}$ Auburn University, Auburn, Alabama, Auburn, AL, 36832; ${ }^{4}$ College of Agricultural, Environmental and Natural Sciences; Tuskegee University, Tuskegee, AL 36088; ${ }^{5}$ School of Animal Science, Mt. Ida College, Newton, MA 02459.

Received: June 5, 2012 / Accepted: September 12, 2012

\begin{abstract}
The effects of varying levels of dietary peanut skins (PS) inclusion on dry matter intake (DMI), growth, and carcass characteristics of lambs was assessed in 135-d feeding trial. We hypothesized that supplementing lambs' diet with increasing levels of PS would increase DMI, enhance body growth, and impact carcass characteristics. Thus, the overall objective of the study was to gain a thorough understanding of the feeding value of PS to lambs. Twelve Gulf Coast ewe lambs (27.75 $\pm 0.93 \mathrm{~kg}$ initial body weight (BW) and 7 to 8 months of age) were blocked by BW and were randomly assigned within block to 1 of the 3 dietary treatments. Lambs were grouped in 2 pens per treatment ( 2 lambs/pen; $n=4 /$ dietary treatment) with pen serving as the experimental unit. Lambs were fed dietary treatments containing 0 (control), 20, or $40 \%$ PS (DM basis) as a replacement for corn and SBM. Control diet contained dry-rolled corn, SBM, and fescue/Bermuda grass hay at forage to concentrate ratio of $63: 37$. All diets were formulated to meet or exceed the NRC requirements of the finishing lambs. At the end of the feeding trial, lambs were slaughtered, and carcass data were collected after a 48-h chill. Dry matter intake and final BW were not different among treatments $(P>0.05)$. Also, no differences were observed in hot carcass weight ( $\mathrm{HCW} ; \mathrm{P}=0.57$ ), cold carcass weight ( $C C W ; P=0.24)$, body wall fat $(P=0.06)$, 12th rib fat $(P=0.10)$, and kidney and pelvic fat (K\&P fat; $P=0.65$ ) among treatments. However, rib eye area (REA) was greater $(P<0.01)$ in lambs fed $0 \%$ and $20 \%$ PS than in lambs fed $40 \%$ PS. These results suggest that PS can replace a portion of corn and SBM commonly fed to lambs without any ad
\end{abstract}

*Corresponding author: gamal.abdrahim@aamu.edu verse effects on carcass characteristics or lambs performance. Thus, PS needs to be seriously considered as a potential lowcost feedstuff for ruminants.

Key Words: Carcass, meat sheep, peanut skins, feed.

Abbreviations: $A D F$, acid detergent fiber; $A D G$, average daily gain; BW, body weight; CCW, cold carcass weight; $\mathrm{CP}$, crude protein; DDGS, dried distillers grains with solubles; DM, dry matter; DMI, dry matter intake; HCW, hot carcass weight; K\&P fat, kidney and pelvic fat; ME, metabolizable energy; NFC, nonfibrous carbohydrate; NDF, neutral detergent fiber; PS, peanut skins; $P$, phosphorus; REA, rib eye area; $S$, sulfur; SBM, soybean meal; UMC, urea-molasses cake; TDN, Total digestible nutrients.

\section{Introduction}

Many alternative and by-product feeds, such as dried distillers grains with solubles (DDGS) and cotton seeds, are now available, often at a fairly low cost, to provide supplemental nutrition for ruminants. Peanut skins (PS) are a low-value byproduct of peanut processing operations. Because of its high protein and fat content and low fiber content, PS would be an excellent feed source replacing soybean meal (SBM) in ruminant diets (Utley et al., 1993). However, phenolic compounds found in PS, such as tannins can have detrimental effects on animal performance (Price and Butler, 1980; Hill et al., 1986a; Hill et al., 1986b; Utley et al., 1993). Tannins are known to bind with enzymes and form nutritionally unavailable polymers with 
dietary proteins (Jung and Fahey, 1983). Various methods can be used to eliminate the detrimental effects of tannins such as feeding extra crude protein (CP), supplementing diet with ureamolasses cake (UMC), and feeding ammonia-treated PS (Jung and Fahey, 1983).

Increasing dietary protein allows higher levels of PS to be fed to finishing steers without encountering effects on digestibility and performance (McBrayer et al., 1983; Hill et al., $1986 a, b)$. The levels of PS included would be dependent upon the amount of excess protein present in the diet as well as the cost of the PS as a feed ingredient (McBrayer et al., 1983). Under proper conditions, feeding of PS to cattle grazing winter annual pastures appears practical at up to $9 \%$ of the dry matter intake (DMl; McBrayer et al., 1983). A limited number of research studies have examined the effects of feeding high levels of PS in the diets of ruminant animals on carcass quality and animal performance (Hill et al., 1986b; Hill et al., 1987; West et al., 1993). Therefore, we hypothesized that up to $40 \%$ PS inclusion (DM basis) would result in beneficial influence on the performance of finishing ewe lambs. The overall objective of the study was to determine the influence of feeding high levels of PS on DMl, final body weight (BW), average daily gain (ADG) and carcass characteristics of lambs.

\section{Materials and Methods}

\section{Experimental Design}

All animal care and handling procedures followed the farms written guidelines set forth by Federation of Animal Science Society (1999) and all procedures involving animals were approved by the Animal Care and Use Committee of Alabama A\&M University (AAMU). A total of Twelve Gulf Coast ewe lambs (27.75 $\pm 0.93 \mathrm{~kg}$ initial BW and 7 to 8 months of age) were used in a completely randomized block design. The study was conducted at the AAMU Winfred Thomas Agricultural Research Station and lasted for 135-days.

\section{Experimental Animals}

Before the start of treatment diets, lambs were grouped according to their BW and randomly assigned within blocks to the three treatments. Treatments had two replicates with two lambs in each ( $n=4$ /dietary treatment). Before initiation of the study, lambs were vaccinated for clostridial disease (Convexin 8 , Schering-Plough, Kenilworth, NJ). During the trial, lambs were housed in pens ( 2 lambs/pen). Pens were $1.50 \times 2.5 \mathrm{~m}$ and were bedded with wood shavings to allow minimal stress on lambs. Pens were equipped with plastic feeders and water buckets. Treatment diets were offered once daily at 0800 AM for ad libitum intake with free access to fresh water. Feed refusals were collected every morning, weighed, dried, and analyzed for DM, and used to calculate DMI.

\section{Peanuł Skins Analysis}

The chemical composition of PS was determined at Nutrition
Laboratory, Inc. (Millersburg, Ohio) before PS was used in the trial (Table 1).

\section{Experimental Diets}

Peanut skins was added at 0,20 or $40 \%$ of the dietary DM to replace corn and SBM. Ingredient and chemical composition of different concentrates containing varying levels of PS were determined at Auburn University before the start of the trial (Table 2). The total diets containing PS were formulated to meet or exceed the NRC (2007) requirements for finishing lamb. Lambs were allowed 7-day adjustment period in the stalls and 7-day transition period to the PS diets followed by $135 \mathrm{~d}$ feeding period.

\section{Data Collection Procedures}

Lambs' initial and final BW were the average of 2 BW taken on two consecutive days. After $135 \mathrm{~d}$ finishing period, lambs were transported to the Auburn University Lambert-Powell meat's laboratory (Auburn, $\mathrm{AL}$ ) for slaughter and subsequent carcass data collection. Carcass data collected by trained personnel after a 48-h chill (temperature $<2{ }^{\circ} \mathrm{C}$, humidity near $100 \%$ ), included final BW, hot carcass weight (HCW), cold carcass weight (CCW), 12 th rib fat, body wall fat, kidney and pelvic fat (K\&P fat), and rib eye area (REA).

Table 1. Nutrient composition of Peanut Skins.

\begin{tabular}{|c|c|c|}
\hline Item & Units & DM basis \\
\hline$\overline{\mathbf{C P}^{1}}$ & $\%$ & 22.68 \\
\hline Available protein & $\%$ & 19.00 \\
\hline Adjusted CP & $\%$ & 21.27 \\
\hline ADF $^{2}$ & $\%$ & 39.62 \\
\hline$N^{\prime} F^{3}$ & $\%$ & 32.66 \\
\hline ADF protein & $\%$ & 3.68 \\
\hline NDF protein & $\%$ & 6.08 \\
\hline $\mathrm{NFC}^{4}$ & $\%$ & 28.41 \\
\hline Lignin & $\%$ & 12.13 \\
\hline Starch (est.) & $\%$ & 26.99 \\
\hline Crude fat & $\%$ & 19.05 \\
\hline TDN $^{5}$ & $\%$ & 87.66 \\
\hline NEI & Mcal/lb. & 0.919 \\
\hline NEm & Mcal/lb. & 0.984 \\
\hline NEg & Mcal/lb. & 0.676 \\
\hline Ash & $\%$ & 2.70 \\
\hline Lignin insoluble ash & $\%$ & 0.22 \\
\hline Calcium & $\%$ & 0.25 \\
\hline Phosphorus & $\%$ & 0.15 \\
\hline Magnesium & $\%$ & 0.11 \\
\hline Potassium & $\%$ & 0.64 \\
\hline Sulfur & $\%$ & 0.12 \\
\hline Sodium & $\%$ & 0.25 \\
\hline Copper & ppm & 46 \\
\hline Manganese & ppm & 32 \\
\hline Zinc & ppm & 47 \\
\hline Iron & ppm & 262 \\
\hline
\end{tabular}

Crude Protein. ${ }^{2}$ Acid detergent fiber. ${ }^{3}$ Neutral detergent fiber. ${ }^{4}$ Non-fibrous carbohy drate. ${ }^{5}$ Total digestible nutrients. 
Table 2. Ingredient and chemical composition of different concentrates containing varying levels of Peanut skins (PS) and fescue/bermudagrass hay (F/BGH; $/ \mathrm{kg}$, DM basis).

\begin{tabular}{|c|c|c|c|}
\hline \multirow[t]{2}{*}{ Item $^{1}$} & \multicolumn{3}{|c|}{ Diet (DM basis) } \\
\hline & $0 \%$ PS (control) & $20 \%$ PS & $40 \%$ PS \\
\hline Concentrate & 63.0 & 64.4 & 63.8 \\
\hline F/BGH & 37.0 & 35.6 & 36.2 \\
\hline Total & 100 & 100 & 100 \\
\hline \multicolumn{4}{|c|}{ Concentrates ingredients } \\
\hline & $0 \%$ PS (control) & $20 \%$ PS & $40 \%$ PS \\
\hline Cracked corn & 49.5 & 36.2 & 21.1 \\
\hline Soybean meal ( $48 \% \mathrm{CP})$ & 12.2 & 6.9 & 1.4 \\
\hline Peanut skins & --- & 20 & 40 \\
\hline Sheep Premix ${ }^{2}$ & 1.3 & 1.3 & 1.3 \\
\hline Total & 63.0 & 64.4 & 63.8 \\
\hline \multicolumn{4}{|c|}{ Chemical composition of the experimental diets } \\
\hline Item & 0\% PS (control) & $20 \%$ PS & $40 \%$ PS \\
\hline DM & 88.0 & 89.5 & 90.2 \\
\hline CP, \% of DM & 15.7 & 17.0 & 18.5 \\
\hline Ether extract, \% of DM & 3.0 & 5.2 & 6.5 \\
\hline NDF, $\%$ of DM & 33.0 & 35.0 & 36.0 \\
\hline ADF, $\%$ of $\mathrm{DM}$ & 20.1 & 21.9 & 22.0 \\
\hline Tannins, $\%$ of DM & 1.6 & 4.4 & 5.7 \\
\hline Ash, $\%$ of DM & 4.0 & 4.8 & 4.0 \\
\hline
\end{tabular}

${ }^{1}$ All values are on DM basis (unless otherwise indicated). ${ }^{2}$ (\%) Ca 9.0, P 8.0, Salt 41.0, K 0.10, Mg 1.0; (ppm) Cu 1,750, Se 25.0, Zn 7,500, and (IU/kg) Vitamin A 308,644, Vitamin D 24,251 and Vitamin E 1,653.

Table 3. Dry matter intake (DMI), initial body weight (BW), average daily gain (ADG), and final BW for lambs fed different levels of PS'.

\begin{tabular}{|c|c|c|c|c|c|c|}
\hline \multirow[t]{2}{*}{ Items } & \multicolumn{3}{|c|}{ Diet } & \multirow[t]{2}{*}{ SEM } & \multicolumn{2}{|c|}{ P-value ${ }^{2}$} \\
\hline & 0\% PS (control) & $20 \%$ PS & $40 \%$ PS & & Linear & Quadratic \\
\hline DMI, kg/day & 1.71 & 1.72 & 1.73 & 0.02 & 0.46 & 0.82 \\
\hline BW & & & & & & \\
\hline Initial BW, kg & 28.68 & 27.75 & 26.83 & 3.88 & 0.76 & 1.00 \\
\hline ADG, kg & 0.12 & 0.12 & 0.10 & 0.03 & 0.55 & 0.77 \\
\hline Final BW, kg & 39.55 & 38.43 & 35.33 & 1.50 & 0.63 & 0.15 \\
\hline
\end{tabular}

${ }^{1}$ Four lambs were assigned to each treatment ( $n=4$ /dietary treatment). ${ }^{2}$ Based on orthogonal contrasts for equally spaced treatments.

\section{Statistical Analysis}

The experiment was arranged as a complete randomized block, with pen as the experimental unit, and data were analyzed according to linear and quadratic orthogonal contrasts. Assumptions of normality were tested in the experiment using the UNIVARIATE procedure (SAS, 2006). The GLM procedure of SAS was used to statistically analyze performance and carcass characteristics. The effects of treatment and block were included in the model statement for each experiment. Least squares means were generated and separated using the PDIFF option of SAS for significant main effects. The protected F-test was used to determine overall significance where $P$-values of 0.05 were considered significant.

\section{Results}

\section{Lambs Overall Performance and Carcass Characteristics}

No differences $(P>0.05)$ in DMI, ADG or final BW were observed among treatment diets (Table 3 ). Similarly, no effects ( $P$ $>0.06$ ) on $\mathrm{HCW}, \mathrm{CCW}, 12$ th rib fat, body wall fat, and K\&P fat were observed when 20 or $40 \%$ PS was included in lamb's diets (Table 4). However, REA was lower $(P<0.01$ ) for lambs fed the $40 \%$ diet compared to lambs fed the 0 or $20 \%$ diets (Table 4 ).

\section{Discussion}

\section{Feed Intake}

The lack of differences in DMI among treatments may be caused by the similar NDF concentrations in diets as the NDF concentration in diets is the main dietary constraint for reduced 
Table 4. Hot and cold carcasses weight for lambs fed different levels of PS'.

\begin{tabular}{|c|c|c|c|c|c|c|}
\hline \multirow[t]{2}{*}{ Items } & \multicolumn{3}{|c|}{ PS \% (Diet) } & \multirow[t]{2}{*}{ SEM } & \multicolumn{2}{|c|}{ P-value ${ }^{2}$} \\
\hline & 0\% PS control) & $20 \%$ PS & $40 \%$ PS & & Linear & Quadratic \\
\hline \multicolumn{7}{|c|}{ Carcass characteristics } \\
\hline $\mathrm{HCW}^{3}, \mathrm{~kg}$ & 17.73 & 17.40 & 16.95 & 0.87 & 0.57 & 0.96 \\
\hline $\mathrm{CCW}^{4}, \mathrm{~kg}$ & 15.7 & 14.80 & 13.90 & 0.90 & 0.24 & 0.99 \\
\hline $12^{\text {th }}$ Rib fat, cm & 0.35 & 0.28 & 0.15 & 0.06 & 0.10 & 0.75 \\
\hline Body wall fat, cm & 1.30 & 1.18 & 0.43 & 0.21 & 0.06 & 0.31 \\
\hline$K \& P f a t^{5}, \mathbf{k g}$ & 0.38 & 0.33 & 0.35 & 0.04 & 0.65 & 0.45 \\
\hline $\operatorname{REA}^{6}, \mathrm{~cm}^{2}$ & $1.88^{a}$ & $2.4^{\mathrm{a}}$ & $1.0^{\mathrm{b}}$ & 0.08 & 0.01 & 0.003 \\
\hline
\end{tabular}

${ }^{1}$ Four lambs were assigned to each treatment ( $n=4$ /dietary treatment). ${ }^{2}$ Based on orthogonal contrasts for equally spaced treatments. ${ }^{3}$ Hot carcass weight. ${ }^{4}$ Cold carcass weight. ${ }^{5}$ kidney and pelvic fat. ${ }^{6}$ Rib eye area. a,b Means without common superscript letters differ $(P<0.05)$.

DMI in ruminants (Van Soest, 1994). Results of DMI are consistent with West et al. (1993) when cows where fed diets contained 0 or $16 \%$ PS. However, West et al. (1993) noticed that DMI decreased when cows were fed diets that contain 24\% PS. McBrayer et al. (1983) reported a decrease in DMI when $20 \%$ PS was included in diets of growing-finishing cattle.

\section{Weight Gain}

In agreement with our study, Utley and Hellwig (1985) reported no differences in ADG in calves fed either 0 or $10 \%$ PS. Similarly, Hill et al. (1986a) observed that BW and ADG did not differ for steers fed control diet and high-protein PS diet with soybean. However, McBrayer et al. (1983) noticed that feeding $10 \%$ PS diet increased ADG for heifers compared to $20 \%$ PS diet. Furthermore, McBrayer et al. (1983) reported that ADG of heifers fed control diet and attained slaughter weight by $72 \mathrm{~d}$ on feed was higher than those failed to attain slaughter weight by $100 \mathrm{~d}$ when fed 10 and $20 \%$ PS diets.

\section{Carcass Characteristics}

There were no differences in carcass characteristics between treatments except for REA, which was significantly higher for lambs fed the $40 \%$ PS. Results in the present study agree with previous research (Hill et al., 1986b; Hill et al., 1987) except for REA. Hot carcass weight in lambs fed the 40\% PS (16.95 kg) was numerically less than that of the $0 \%$ and $20 \%$ PS $(17.73$ and $17 \mathrm{~kg}$, respectively; Table 4). Meanwhile, the REA was significantly lower when $40 \%$ PS was included in lambs finishing diets (Table 4). In agreement with the results of the current study, except for the REA, Hill et al. (1987) noticed that carcass characteristics were similar for steers fed diets with 15\% PS. Also, Hill et al. (1986b) noticed that carcass characteristics of steers on diets included different levels of PS were remarkably uniform and no significant differences were observed. The same authors also noticed that carcass weight and internal fat were higher in steers fed diet included urea-molasses cake (UMC)-supplemented PS compared with control. Hill et al. (1986b) concluded that the detrimental effects of tannins when PS was included in steers' diets may be avoided by increasing dietary $C P$ level with high SBM or SBM plus UMC-supplemented diets. Furthermore, Hill et al. (1986b) observed that carcass characteristics of heifers fed different levels of dietary PS were similar, except for dressing percentage, which was significantly higher for control heifers.

\section{Conclusion}

The current study demonstrated that feeding increasing level of PS to lambs significantly impacted the REA. However, no differences were observed in DMl, final BW, HCW, CCW, body wall fat, 12th rib fat, and K\&P fat among treatments. Peanut skins contain appreciable quantities of both protein and fat that makes it an excellent feed source. The potential for PS to reduce performance, due to the impact of PS tannin on protein metabolism is of concern in marginally adequate CP diets. However, small ruminants have been shown to be especially adept at handling moderately high levels of tannins in their diet. Thus, PS needs to be considered as a potential low-cost feedstuff for ruminants. Future studies needed to further evaluate the advantage of feeding PS.

\section{Acknowledgments}

This manuscript is based on research funded by the Alabama Agricultural Land Grant-Alliance. We thank the staff at the AAMU Winfred Thomas Agricultural Research Station and the Department of Food \& Animal Sciences for their support throughout the study. Also, we wish to thank Dr. Jorge Vizcarra for assistance with statistical analyses, Auburn University Lambert-Powell meat Laboratory for assistance with carcass evaluation, and Dr. James Shuford (former Dean of the College of Agricultural, Life and Natural Sciences at AAMU) for his comments on the manuscript.

\section{References}

Federation of Animal Science Society (1999) Guide for the Care and Use of Agricultural Animals in Agricultural Research and Teaching. 1 st rev. ed. Fed. Animal Science Society, Savoy, IL.

Hill GM, PR Utley, and GL Newton (1986a) Digestibility and utilization of ammonia-treated and Urea-Supplemented Peanut Skin Diets Fed to Cattle. J. Anim Sci. 63: 705-714.

Hill GM, PR Utley, and GL Newton (1986b) Influence of dietary Crude protein on Peanut Skin Digestibility and Utilization by Feedlot Steers. 
J. Anim. Sci.62: 887-894.

Hill GM, PR Utley, and Newton GL (1987) Dietary Urea influences on Digestibility and Utilization of Diets Containing Peanut Skins by Steers. J. Anim Sci. 64: 1-7.

Jung HG, and GC Fahey (1983) Nutritional implications of phenolic monomers and lignin: A review. J. Anim. Sci. 57 (1): 206-219.

McBrayer AC, PR Utley, RS Lowrey, and WC McCormick (1983) Evaluation of Peanut Skins (Testa) as a feed Ingredient for growing-Finishing Cattle. J. Anim Sci. 56: 173-183.

National Research Council (2007) Nutrient Requirements of small ruminants: Sheep, Goats, Cervids, and New World Camelids, National Academy Press, Washington, DC.

Price ML, and LG Butler (1980) Tannins and nutrition. Agr. Exp. Sta. Bull. No. 272.

Purdue Univ., Lafayette. In: Hill et al. (1986) Digestibility and Utili- zation of Ammonia-Treated and Urea-Supplemented Peanut Skin Diets Fed to Cattle. J. Anim Sci. 63: 705-714.

SAS Institute. SAS User's Guide: Statistics. Cary, NC: SAS Inst. Inc.; 2006; Version 9.1.3.

Utley PR, and RE Hellwig (1985) Feeding value of Peanut skins added to Bermudagrass Pellets and Fed to Growing beef Calves. J. Anim Sci. 60: 329-333.

Utley PR, GM Hill, JW West (1993) Substitution of peanut skins for soybean hulls in steer finishing diets containing recommended and elevated crude protein levels. J. of Anim Sci. 71: 33-37.

Van Soest PJ (1994) Nutritional Ecology of the Ruminant. 2nd ed. Cornell University Press, Ithaca, NY.

West JW, PR Utley, GM Hill (1993) Peanut skins as a feed Ingredient for Lactating Dairy Cows. J. Dairy Sci. 76: 590-599. 